\section{Lord Cable}

Bruce J. Hunt,

Associate Professor, Department of History, University of Texas at Austin, USA

$S^{\mathrm{i}}$ ir William Thomson (1824 - 1907), better known to later gen$\mathcal{S}$ erations as Lord Kelvin, was the quintessential Victorian physicist. Today most of us would probably place him a little below his younger and shorter-lived contemporary James Clerk Maxwell (1831 - 1879), but in his own day, Thomson was invariably ranked at the top. Appointed Professor of Natural Philosophy at the University of Glasgow at age 22, he made fundamental contributions in many areas of physics: with Rudolf Clausius, he was the first to state the Second Law of Thermodynamics; he originated the absolute temperature scale, now known as the Kelvin scale; he did pioneering work in electrical theory; and he devised important instruments for precision electrical measurement. $\mathrm{He}$ was also active on the technological side, particularly in submarine telegraphy. In 1867 he was knighted for his work on the first Atlantic cables, and by the 1870 s he was earning a large income as a consultant to cable companies and through his patents on telegraphic instruments - enough to buy a yacht and build a large country house. In fame and fortune, and in the personal satisfaction that comes from doing important and interesting work, physics paid off handsomely for Thomson.

In January 1892, Thomson was raised to the peerage and, as a newly minted baron, had to pick a new name for himself, since "Lord Thomson" was already taken. He soon settled on "Kelvin," after a small river that ran near his Glasgow laboratory, but only after friends had half-jokingly suggested that he call himself "Lord Cable." It would have been an apt choice, reflecting not only the chief source of his wealth and fame, but also the inspiration for some of his best scientific work. We might find it odd now to think of quoting absolute temperatures on the "Cable" scale, but if Thomson had chosen that name, it would continually remind us just how closely science and technology were intertwined in his career.

The first successful submarine cable was laid across the English Channel in 1851. Most early cables consisted of one or more copper wires insulated with a few millimeters of gutta percha, a rubber-like tree gum from Malaya, and protected by an outer layer of iron wires. In the early 1850 s telegraphers noticed that sharply defined signals sent into one end of such a cable emerged at the other slightly delayed and greatly distorted, so that signals sent in rapid succession blurred together and became unreadable. Michael Faraday looked into such "retardation" phenomena in 1853 and soon identified capacitance as the source of the problem. When a telegraph key is pressed and the wire is connected to the battery, he said, a steady current cannot flow until the wire first acquires its full electrostatic charge. Since most land lines were simply bare wires strung from poles, they could store so little charge that the whole process occurred almost instantaneously, producing little or no retardation. Submarine cables, by contrast, were practically long tubular capacitors; they could store enormous amounts of charge, and the resulting retardation severely limited signalling rates along them. Reducing retardation became the great goal of cable telegraphers.

Thomson took up the problem in 1854, analyzing it using equations drawn from Fourier's theory of heat flow. He showed that when resistance and capacitance dominate, as they generally do, electrical signals diffuse along a cable much like pulses of heat passing down an iron rod - though of course far more quickly. The time lag before the current at the far end rises to a detectable level is proportional to both the total resistance and total capacitance of the cable, and so to the square of its length. Retardation on a really long cable could thus become very bad indeed.

This was bad news for the ambitious promoters of a cable across the Atlantic. A telegraphic link between London and New York (via Ireland and Newfoundland) held the promise of enormous profits, but if Thomson was right, retardation would evidently prevent such a long cable from being able to carry enough traffic to pay for itself. At this point Wildman Whitehouse, an English surgeon turned electrical experimenter, announced that his tests on cables contradicted Thomson's "law of squares"; the law was "a fiction of the schools," Whitehouse declared, and retardation posed no real obstacle to the success of an Atlantic cable. The delighted promoters of the Atlantic Telegraph Company made Whitehouse their official "electrician" in October 1856 and put him in charge of all electrical arrangements for the planned cable. Thomson stood by his theory, and Whitehouse eventually conceded its validity "as theory," while Thomson agreed that with proper handling, it might be possible to reduce the effects of retardation enough to make an Atlantic cable a paying proposition.

At the end of 1856, Glasgow investors elected Thomson to the board of directors of the Atlantic Telegraph Company, and he threw himself into the cable project. While Whitehouse was being paid enormous sums for his own patented signalling instruments, Thomson worked privately to devise the mirror galvanometer, an exquisitely sensitive instrument that used a wieghtless beam of reflected light as its "pointer," enabling it to respond to even very weak currents. Thomson's little instrument would be used in cable testing rooms and electrical laboratories for decades to come.

When ill health kept Whitehouse from sailing with the cablelaying expeditions, Thomson volunteered to take his place, supervising shipboard electrical arrangements on the abortive first attempt in August 1857, when the cable snapped after only a few hundred miles had been laid, and on the repeated attempts in 1858 , culminating in the successful completion of the cable from Ireland to Newfoundland on August 5.

The first Atlantic cable was greeted as the wonder of the age; one celebration in New York became so spirited that City. Hall caught fire and nearly burned down. Unfortunately, the cable had been hurriedly made and roughly handled; moreover, when the Irish end was handed over to Whitehouse, he set aside Thomson's mirror galvanometer and subjected the cable to jolts of current from his own equipment - including an induction coil five feet long - that further damaged its already fragile insulation. Exasperated by Whitehouse's inability to send or receive readable signals, the company removed him in mid-August and put Thomson in charge. Using battery currents and his mirror galvanometer, Thomson managed to send and receive a significant number of messages, but the damage had already been done, and within a few weeks, the cable was dead.

The first Atlantic cable was a spectacular failure whose collapse tainted the reputation of ocean telegraphy as a whole. While Whitehouse was saddled with much of the blame, Thomson drew almost universal praise, with the implication that if his scientific advice had been followed more closely, the cable might have succeeded. An official inquiry in 1861 nearly said as much, and as the Atlantic Telegraph Company regrouped to try again, it 
pledged to build its new cable to scientific specifications. In the meantime, Thomson pushed for adoption of measures to ensure that such specifications could be followed and enforced. It was largely at his urging that the British Association for the Advancement of Science formed its Committee on Electrical Units in 1861 , and he played a leading role as the committee proceeded to produce essentially the system of ohms, amps, and volts still used today.

By 1865 the Atlantic Telegraph Company was ready to try again, using a new and thicker cable. Thomson again sailed with the expedition, this time on the Great Eastern, but two-thirds of the way across, the cable snapped and sank. Undaunted, the backers raised more money, ordered another cable, and set out yet again the next year. This time everything went smoothly and the cable was landed at Heart's Content, Newfoundland, on 27 July 1866. The Great Eastern then returned to where the cable had parted the year before, grappled it up from the bottom of the ocean, spliced on a new length, and completed it to Newfoundland on September 7. The Atlantic was thus spanned by two working cables, and Europe and North America have been in direct telegraphic contact ever since.

In the 1860 s Thomson formed a partnership with two cable engineers, Fleeming Jenkin and C. F. Varley, and within a few years, each was bringing in several thousand pounds a year in consulting fees and patent royalties - this at a time when a few hundred pounds a year was a good academic salary. Thomson followed up his mirror galvanometer with the siphon recorder, an "ink jet" device that used a delicate pivoted glass tube to paint a wavy line on a moving paper tape, recording messages in the bumps and dips of Morse code. By the mid-1870s, as big British firms rapidly laid cables to India, Australia, the Far East, and South America, as well as new lines across the North Atlantic, Thomson could boast that all long distance cable traffic was handled by instruments he had invented.

Even as his telegraphic work grew in the 1870s, Thomson continued to publish prolifically on electromagnetism, hydrodynamics, the age of the earth, the design of navigational gear, and other topics both scientific and technological. As he rose to the top of the scientific world, serving as president of the Royal Society, the British Association, the Institution of Electrical Engineers, and other organizations, he began to fall behind the advancing frontier of research. Except for a few years after 1888, when he was caught up in the excitement surrounding Heinrich Hertz's discovery of electromagnetic waves, Thomson never took up Maxwell's field theory, and it was left to others, particularly Oliver Heaviside, to show how the theory could be applied to telegraphic propagation problems.

When Thomson was born in 1824, the fastest means of travel were the sailing ship and the horse drawn coach, and a message could travel no faster than the messenger who carried it. By the time he died in 1907, steamships were plowing the seas, railways crisscrossed the continents, and the first airplanes were taking to

\footnotetext{
- Fig. 1: An early photograph of William Thomson, later Lord Kelvin, reading a letter in 1859 from his your engineering protege Fleeming Jenkin on submarine telegraph experiments. Thomson had played a leading role in the effort to lay the first telegraph cable across the Atlantic the year before, and after it failed after only a month of fitful service, he worked hard to ensure that future efforts would succeed. From: Agnes Gardner King, Kelvin the Man: A biographical sketch by his niece (London: Hodder and Stoughton, 1925).
}

the skies. The global network of telegraph lines and submarine cables had rendered communications almost instantaneous, and the first systems of wireless telegraphy were reaching out into what was still known as the ether. In less than a century, the world had been transformed, not least through the work of Thomson himself.

Throughout the nineteenth century, Thomson and other scientists were repeatedly drawn into disputes about the relative value of practice versus theory, as "practical men" they claimed that their own experience, not scientific theories, gave the best guide to technological progress. From the time of his controversy with Whitehouse, Thomson always preached the "harmony" of

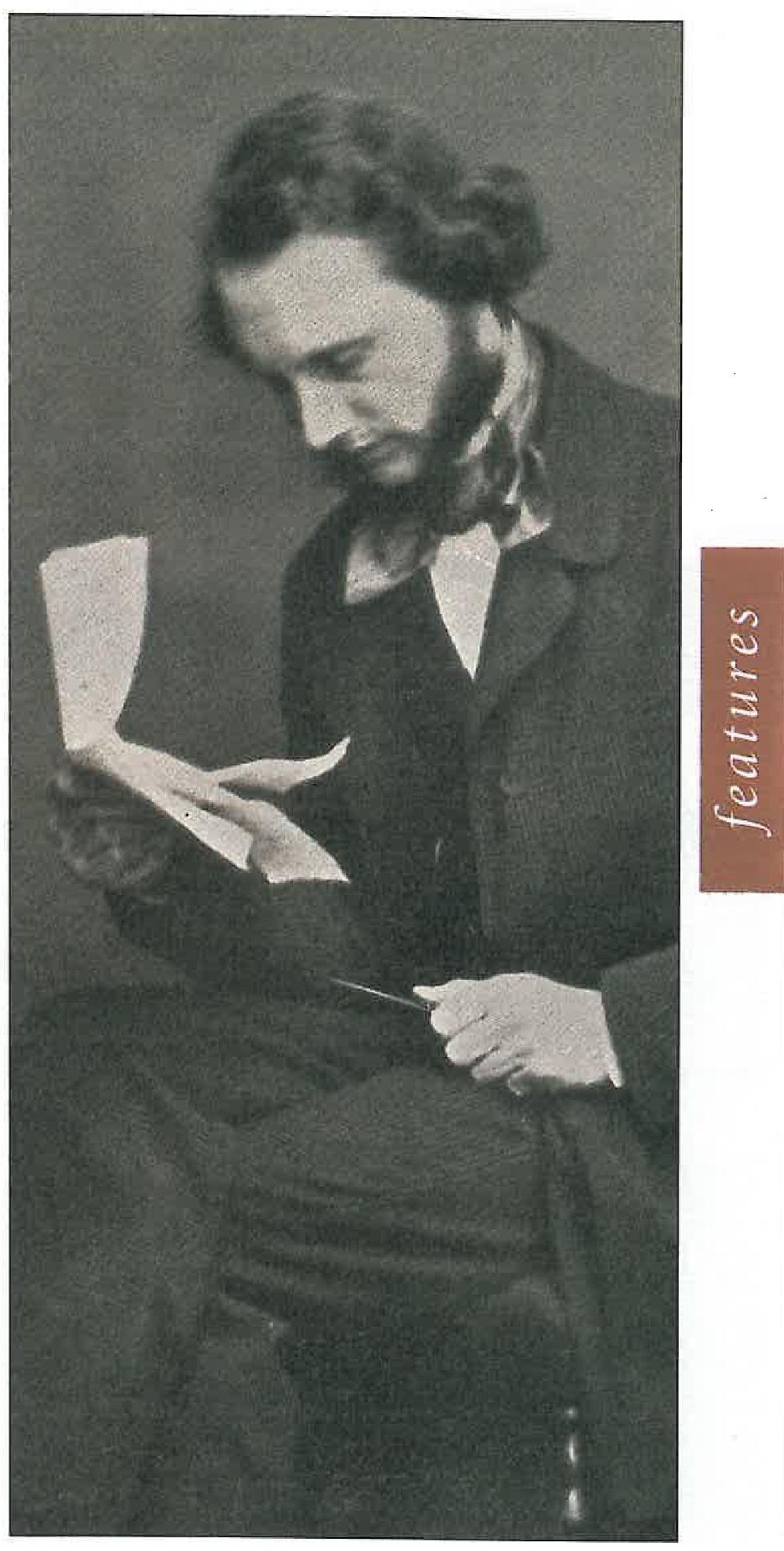


science and technology, proclaiming that when properly pursued, each served to advance the other. Scientific knowledge had been vital to the eventual success of cable telegraphy, Thomson said, while the growth of the cable industry had produced a demand for knowledge and opportunities for acquiring it notably in the confrontation with retardation phenomena - that had led to great advances in the scientific understanding of electromagnetism.

Thomson exemplified this fruitful interaction in his own research and in his Glasgow laboratory, the first physics teaching laboratory in any British university. There he set his advanced students to work on problems arising from cable projects, often as direct as having them measure the resistance of samples of wire, and trained many of them for careers as cable engineers. Beginning in the 1870s, Thomson even used part of his cable earnings to endow physics scholarships at the university, thus not just reinvesting in the scientific and technological enterprise that had paid off so well for him, but contributing to what, in his characteristic Victorian fashion, he saw as the best path to the larger progress of the world as a whole. For Thomson, that path led from the physics laboratory into the market place, but also from the market place back into the laboratory.

\section{About the author}

Bruce J. Hunt is an associate professsor in the History Department at the University of Texas at Austin. He initially studied physics before moving into the history of science. His book The Maxwellians was published by Cornell University Press in 1991, and he is now working on a study of the relationship between telegraphy and electrical science in Victorian Britain.

\section{References}

For more on the life and work of William Thomson (Lord Kelvin), see Crosbie W. Smith and M. Norton Wise, Energy and Empire: A Biographical Study of Lord Kelvin (Cambridge: Cambridge University Press, 1989).

For an interesting perspective on Thomson, see Denis Weaire's Cecil Powell Memorial Lecture, "The Value of Useless Studies," Europhysics News (2002) Vol. 33.

On the general topic of the interaction between physics and technology in the nineteenth century, see my forthcoming book, Power and Light: Physics and Technology from James Watt to Albert Einstein (Baltimore: Johns Hopkins University Press).

- Fig. 2: A painting by C. Lewis showing the Great Eastern and its accompanying flotilla of ships landing the first enduringly successful Atlantic telegraph cable at Heart's Content, Newfoundland, in July 1866. The ships then returned to mid-ocean, grappled up a cable that had snapped during laying the year before, and completed it to Heart's Content in September 1866 , establishing a second working link across the ocean. William Thomson accompanied both expeditions and later that year was knighted for his cable work, becoming Sir William.

From: Cable \& Wireless Archive, Porthcurno Museum of Submarine Telegraphy, Porthcurno, UK.

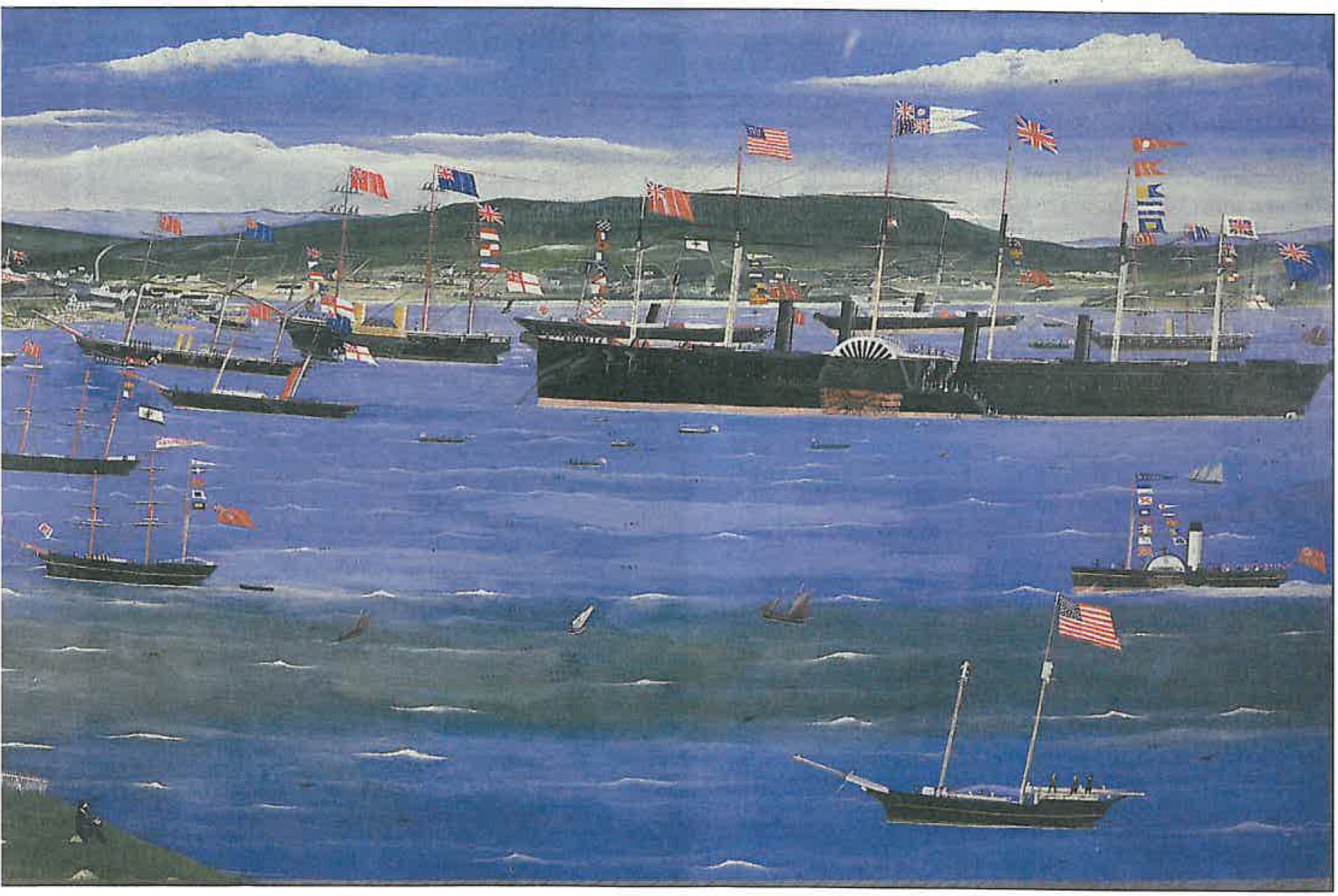

